\title{
PENYUSUNAN MODUL PEMBIASAAN/INTEGRASI KETERAMPILAN PERDAMAIAN DAN RESOLUSI KONFLIK UNTUK SEKOLAH ERENOS, TANGERANG SELATAN
}

\author{
Edwin M. B. Tambunan ${ }^{1}$, Elyzabeth B. Nasution ${ }^{2}$ \\ ${ }^{1}$ Program Studi Hubungan Internasional, Universitas Pelita Harapan \\ ${ }^{2}$ Program Studi Hubungan Internasional, Universitas Pelita Harapan \\ edwin.tambunan@uph.edu, elyzabeth.nasution@uph.edu
}

\begin{abstract}
Abstrak
Menindaklanjuti evaluasi kegiatan Pengabdian kepada Masyarakat (PkM) bertajuk Pendidikan Keterampilan Perdamaian dan Resolusi Konflik untuk Sekolah Erenos yang selesai tahun pelajaran 2018-2019, tim PkM Youth \& Peace Project Program Studi Hubungan Internasional bersama Sekolah Erenos melihat adanya kebutuhan untuk mengintegrasikan pendidikan perdamaian secara berkelanjutan ke dalam Proses Belajar Mengajar (PBM). Upaya ini dianggap penting karena penanaman nilai-nilai perdamaian serta pembangunan karakter pendukungnya merupakan sebuah proses yang tidak serta merta; membutuhkan disiplin, komitmen besar, dan cetak biru untuk mewujudkannya. Untuk itu, tim beserta Sekolah Erenos sepakat untuk melanjutkan PkM ke proses penyusunan modul integrasi. PkM ini bertujuan menghasilkan sebuah modul pembiasaan yang akan digunakan dalam PBM. Di dalamnya, visi misi sekolah bersama dengan nilai dan keterampilan perdamaian disajikan melalui kegiatan intrakurikuler pada ragam mata pelajaran agar para siswa dapat menginternalisasinya. Proses penyusunan modul terbagi dua, yaitu (1) melalui rangkaian Focus Group Discussion (FGD) dan lokakarya, serta (2) penulisan modul. Tim telah berhasil menyelesaikan rangkaian FGD dan lokakarya serta menghasilkan kerangka tulisan yang akan dikembangkan pada tahap berikutnya dan menghasilkan modul yang sepenuhnya menjadi hak milik sekolah.
\end{abstract}

Kata Kunci: Pendidikan Perdamaian, Resolusi Konflik, Pembiasaan, Sekolah Erenos

\section{PENDAHULUAN}

Pada tahun 2018-2019, tim Pendidikan

Keterampilan Perdamaian dan Resolusi Konflik, Program Studi Hubungan Internasional, Universitas Pelita Harapan melaksanakan kegiatan pengabdian kepada masyarakat di Sekolah Erenos, Tangerang Selatan. Pelatihan ini diikuti bergelombang baik oleh siswa-siswa maupun guru-guru. Para siswa berasal dari jenjang SMP dan SMA, sementara para guru berasal dari semua jenjang $(\mathrm{KB} / \mathrm{TK}$ hingga
SMA). Tercatat sebanyak kurang lebih 200 peserta hadir mengikuti kegiatan pelatihan ini.

Siswa-siswa dan guru-guru Sekolah Erenos yang telah mengikuti Program Pelatihan Keterampilan Perdamaian dan Resolusi Konflik merasakan manfaat dan dampak dari kegiatan yang dilakukan. Kegiatan-kegiatan interaktif yang dirancang berdasarkan modul Pendidikan Perdamaian untuk Sekolah Menengah Umum 
(Tambunan 2008) membangunkan dan membentuk kesadaran mereka tentang pentingnya memiliki pengetahuan, sikap, dan keterampilan baru untuk menciptakan komunitas shalom (damai sejahtera).

Pihak Yayasan Erenos juga melihat perubahan yang terjadi setelah para siswa dan guru mengikuti pelatihan dan kemudian menyadari perlunya mengembangkan nilai-nilai dan karakter damai yang telah diadopsi melalui program yang sifatnya berkelanjutan. Untuk itu, sebagai tindak lanjut dari pelatihan yang telah dilaksanakan, sekolah merasakan perlu menyusun suatu pedoman yang dapat menjadi acuan bagi yayasan, pimpinan, dan para guru untuk melaksanakan pembiasaan atau pengintegrasian pengetahuan, sikap, dan keterampilan yang telah diperoleh siswa melalui pelatihan ke dalam proses belajar mengajar maupun aktivitas lainnya di lingkungan sekolah.

Selain bermanfaat untuk membiasakan komunitas sekolah menerapkan nilai-nilai perdamaian dan resolusi konflik, pedoman kegiatan yang hendak disusun juga diharapkan Yayasan Sekolah Erenos menjadi sarana untuk mengimplementasikan visi dan misi serta nilai-nilai sekolah. Atas pertimbangan demikian, pihak Yayasan Erenos kemudian meminta kesediaan Tim PkM Youth \& Peace Project, Program Studi Hubungan Internasional, Universitas Pelita Harapan melanjutkan program pengabdian kepada masyarakat dengan melakukan pendampingan sekaligus memfasilitasi sekolah dalam menyusun modul pembiasaan dan integrasi.

Tim menyambut baik dan menyanggupi permintaan yang diajukan oleh Yayasan Erenos. Setelah melalui sejumlah diskusi pendahuluan dengan pimpinan yayasan, maka tersusunlah kerangka acuan penyusunan modul pembiasaan/integrasi keterampilan perdamaian dan resolusi konflik. Melalui kegiatan yang dijabarkan dalam kerangka acuan diharapkan Sekolah Erenos dapat menyusun dan memiliki Modul Pembiasaan/Integrasi Keterampilan Perdamaian dan Resolusi Konflik yang berisikan rancangan kegiatan-kegiatan yang siap diterapkan dalam proses pembelajaran.

Pembiasaan (habituation) adalah konsep yang dipopulerkan oleh Aristoteles; saat ini sedang mendapatkan perhatian luas dari kalangan akademisi di bidang Pendidikan (Kerr, 2011). Konsep pembiasaan terkait dengan perubahan, penanaman, dan pengembangan karakter melalui pendidikan (Dougherty, 2007). Pembiasaan dapat diartikan sebagai proses perubahan, penanaman, dan pengembangan karakter melalui pembelajaran berulang-ulang berbasis pengalaman. Apabila dikaitkan dengan perdamaian dan resolusi konflik berarti proses penanaman dan pengembangan karakter maupun nilai-nilai perdamaian melalui pengalaman belajar,

\section{METODE}

Penyusunan modul berlangsung dalam dua tahap kegiatan. Tahap pertama adalah persiapan dengan kegiatan utama Focus Group Discussion ditambah lokakarya di antara tahapan FGD apabila diperlukan.

Semula tahap pertama direncanakan akan berlangsung selama enam bulan sejak FGD pertama dilaksanakan 28 Februari 2020. Adapun rincian kegiatan dan hasil yang diharapkan sebagai berikut.

Tabel 1. Rencana Pelaksanaan FGD

\begin{tabular}{|c|c|c|}
\hline FGD & Topik & Luaran \\
\hline 1 & $\begin{array}{c}\text { Visi Sekolah dan } \\
\text { Kontribusi Modul } \\
\text { dalam Pencapaian } \\
\text { Visi }\end{array}$ & $\begin{array}{c}\text { Alur berpikir yang } \\
\text { memperlihatkan } \\
\text { kontribusi modul dalam } \\
\text { pencapaian visi sekolah }\end{array}$ \\
\hline 2 & $\begin{array}{c}\text { Muatan Karakter dan } \\
\text { Nilai }\end{array}$ & $\begin{array}{c}\text { Daftar muatan karakter } \\
\text { dan nilai yang hendak } \\
\text { dibiasakan melalui } \\
\text { kegiatan }\end{array}$ \\
\hline 3 & $\begin{array}{l}\text { Strategi Pembiasaan } \\
\text { atau Integrasi }\end{array}$ & $\begin{array}{l}\text { Pilihan strategi } \\
\text { pembiasaan atau } \\
\text { integrasi dan alur } \\
\text { prosesnya }\end{array}$ \\
\hline 4 & Model Penyajian & $\begin{array}{l}\text { Pilihan model proses } \\
\text { penyajian kegiatan }\end{array}$ \\
\hline 5 & $\begin{array}{l}\text { Alternatif Aktivitas } \\
\text { dan Metode Evaluasi }\end{array}$ & $\begin{array}{l}\text { Daftar aktivitas yang } \\
\text { akan diikutkan dalam } \\
\text { penyajian dan pilihan } \\
\text { metode evaluasinya }\end{array}$ \\
\hline
\end{tabular}

Pendidikan 781 


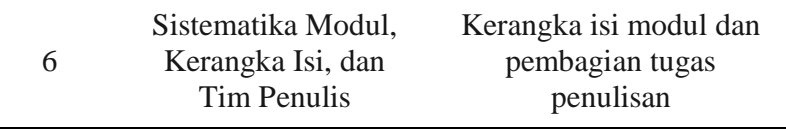

Tahap kedua adalah penulisan modul oleh Tim Sekolah Erenos didampingi oleh Tim UPH, yang semula juga direncanakan akan berlangsung selama enam setelah kerangka isi modul berhasil ditetapkan.

Sayang sekali, perencanaan matang yang telah dilakukan gagal untuk diimplementasikan sepenuhnya menyusul pengumuman Pemerintah Republik Indonesia untuk menerapkan Pembatasan Sosial Berskala Besar (PSBB) sebagai tanggapan terhadap meluasnya pandemi Covid-19 mulai tanggal 30 Maret 2021. Tim UPH dan Tim Sekolah Erenos baru dapat melanjutkan kembali kegiatan pada 11 September 2020 dengan FGD 2. Berturutturut kemudian dilaksanakan FGD 3 pada 19 Februari 2021 dan FGD 4 pada 7 Mei 2021. FGD 5 dan 6 tidak dilaksanakan lagi dan pembahasan maupun luaran untuk dua kegiatan ini diintegrasikan dalam FGD 4.

Selain FGD, dilaksanakan juga tiga kali lokakarya. Kegiatan pertama berlangsung 16 Oktober 2020 untuk merumuskan target luaran FGD 2. Dalam rangka memantapkan luaran FGD 4, lokakarya dilaksanakan sebanyak dua kali, yaitu: 4 Juni dan 23 Juli 2021.

Jumlah peserta yang hadir dalam FGD dan lokakarya bervariasi antara 15 hingga 20 orang, Namun, dalam setiap kegiatan selalu hadir para pengurus yayasan dan perwakilan guru-guru dari jenjang KB/TK hingga SMA.

Saat paper ini ditulis, Tim Sekolah Erenos sedang mengerjakan penulisan isi modul sesuai dengan model penyajian, kerangka isi, dan sistematika yang telah disepakati di FGD 4.

\section{HASIL DAN PEMBAHASAN}

Fasilitasi dan pendampingan yang dilakukan oleh Tim UPH melalui proses FGD dan lokakarya telah berhasil membantu Tim Sekolah Erenos untuk mendapatkan setidaknya empat luaran yang sangat penting artinya dalam proses penyusunan modul pembiasaan yang dikehendaki. Keempat luaran tersebut dijelaskan berturut-turut sebagai berikut.

\section{Kontribusi Modul dalam Pencapaian Visi dan Misi Sekolah (28 Februari 2020)}

Luaran pertama dari fasilitasi yang dilakukan adalah kontribusi modul dalam pencapaian visi dan misi sekolah. Luaraan pertama ini didapat melalui FGD 1 yang berlangsung 28 Februari 2020. Di dalam luaran pertama ini tersusun alur berpikir yang dapat memperlihatkan posisi modul yang hendak ditulis dalam pencapaian visi dan misi Sekolah Erenos. Sesuai dengan harapan Yayasan Sekolah Erenos, modul yang hendak ditulis diarahkan pada satu tujuan yang spesifik yaitu berkontribusi terhadap pencapaian visi dan misi. Dengan demikian, isi modul pembiasaan harus memiliki keselarasan dengan visi dan misi sekolah. Modul yang hendak disusun diharapkan berisi kegiatan-kegiatan yang mengembangkan karakter siswa selama belajar di Sekolah Erenos berdasarkan nilai-nilai perdamaian dan nilai-nilai yang dimiliki sekolah.

Fasilitasi dalam FGD 1 juga mengajak peserta untuk kembali memikirkan visi dan misi sekolah dan dari sana kemudian dipandu untuk menyusun daftar ekspektasi dan kebutuhan. Peserta akhirnya berhasil merumuskan secara konkret daftar ekspektasi karakter yang diharapkan dari modul yang hendak disusun sesuai dengan visi dan misi sekolah dan yang perlu dikembangkan dalam diri siswa selama menempuh pendidikan di Sekolah Erenos. Daftar ekspektasi karakter inilah yang diharapkan akan diperkuat melalui modul pembiasaan yang hendak disusun. 
Sekolah Erenos memiliki visi yaitu "membangun manusia seutuhnya dengan fokus pada Kristus sehingga menghasilkan lulusan yang beriman, berilmu dan memiliki karakter Kristiani serta mendatangkan damai sejahtera bagi diri sendiri dan sesama manusia." Dari kata kunci "karakter Kristiani" dan "damai sejahtera," peserta merumuskan ekspektasi mereka tentang karakter yang harus dimiliki setiap siswa selama belajar, antara lain: takut akan Tuhan, berdamai dengan (menghargai) diri sendiri, berdamai dengan (mengasihi) sesama, menghargai orang lain (teman, guru, orang tua, sesama lainnya), berdamai dengan (memelihara) alam, keteladanan, kepeloporan, kepemimpinan, penatalayanan, kemandirian, bertanggung jawab, dan sifat koperatif. Kegiatankegiatan yang akan disusun dalam modul diharapkan membantu pengembangan karakaterkarakter tersebut sehingga modul betul-betul

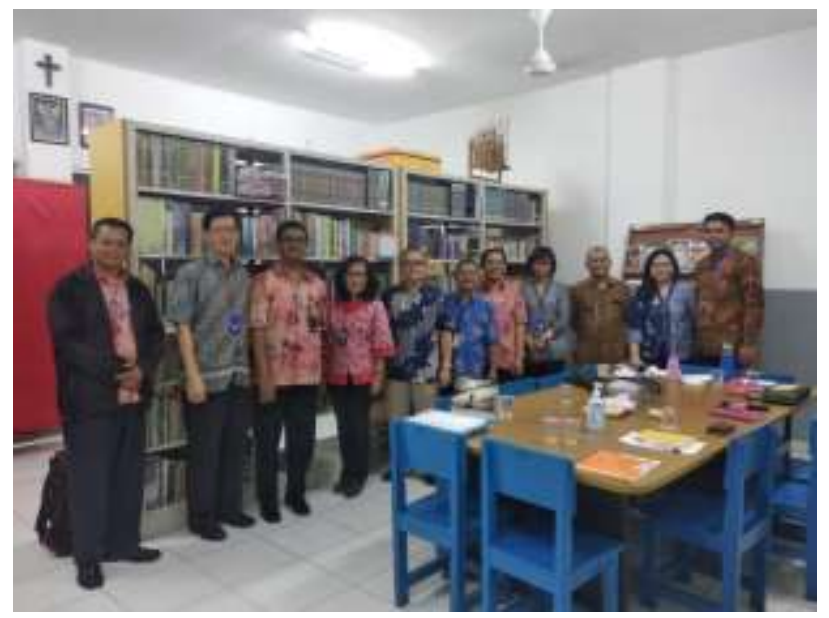

berkontribusi terhadap pencapaian visi sekolah.

Gambar 1. Dokumentasi FGD 1 (Sekolah Erenos, 28 Februari 2020)

\section{Daftar Muatan Karakter dan Nilai}

Luaran yang kedua adalah daftar muatan karakter dan nilai yang dihasilkan melalui fasilitasi dalam FGD 2 yang berlangsung pada 11 September 2020 dan lokakarya yang diselenggarakan sesudahnya. Keberhasilan menemukan karakter dasar yang diturunkan dari visi sekolah pada FGD 1 mengantar peserta untuk maju memperdalam dan mengembangkan muatan karakter dan nilai di FGD 2. Tujuan dari FGD 2 adalah memfasilitasi peserta untuk mengidentifikasi dan menyepakati muatan karakter yang akan menjadi kerangka dasar penyusunan modul integrasi. Dengan demikian selama proses FGD 2 peserta diarahkan untuk dapat merumuskan secara lengkap daftar muatan karakter dan nilai yang kelak akan dibiasakan melalui kegiatan-kegiatan yang disajikan dalam modul. Peserta difasilitasi dengan bantuan tiga pertanyaan. Pertama, karakter mana yang belum tercakup dalam laporan yang disampaikan fasilitator, tetapi sudah terbahas dalam FGD 1? Kedua, karakter apalagi yang perlu ditambahkan untuk melengkapi upaya sekolah mewujudkan visi melalui modul yang akan disusun? Ketiga, bagaimana proses yang harus ditempuh agar bisa mendapatkan rumusan pemahaman yang baik untuk masing-masing

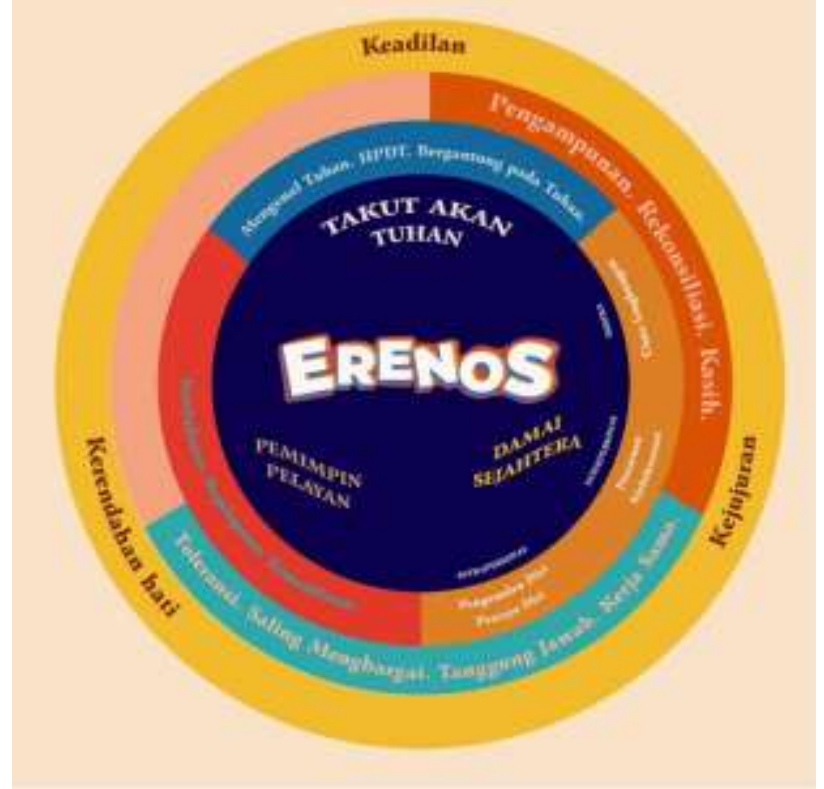

karakter dan indikator-indikator pencapaiannya?

\section{Gambar 2. Karakter dan Nilai-nilai yang akan Dituangkan dalam Modul}

Luaran kegiatan dari FGD 2 untuk pertanyaan pertama dan kedua dirumuskan sebagaimana tertera dalam Gambar 2. Visi Sekolah Erenos diharapkan tercapai melalui pengembangan tiga karakter melalui kegiatan-kegiatan yang kelak dituangkan dalam modul. Tiga karakter dimaksud 
adalah: takut akan Tuhan, damai sejahtera, dan pemimpin pelayan. Pembentukan masing-masing karakter diharapkan terwujud dengan menanamkan nilai-nilai di bawahnya yang akan dibiasakan melalui kegiatan-kegiatan dalam modul. Lingkaran konsentris yang kedua terdiri dari nilai-nilai utama untuk masing-masing karakter. Di dalam lingkaran konsentris yang ketiga tertera nilai-nilai yang beririsan di antara dua karakter. Pada lingkaran konsentris yang keempat terdapat nilai-nilai umum yang berkontribusi kepada pembentukan semua karakter.

FGD 2 ditindaklanjuti dengan lokakarya dalam rangka menuntaskan rumusan yang diharapkan sebagai jawaban untuk pertanyaan ketiga. Di dalam lokakarya, peserta sepakat untuk mengoperasionalkan karakter dan nilai yang telah ditetapkan ke dalam rumusan yang lebih konkret dengan memberi penjelasan atas karakter utama, mendefinisikan semua nilai, mengidentifikasi indikator pencapaian untuk semua nilai, dan mendaftar kegiatan-kegiatan yang mungkin dilakukan untuk membiasakannya dalam kelas. Lokakarya ini berhasil merumuskan sebuah matriks yang menjadi blueprint bagi Sekolah Erenos untuk memulai menyusun modul pembiasaan yang diharapkan.

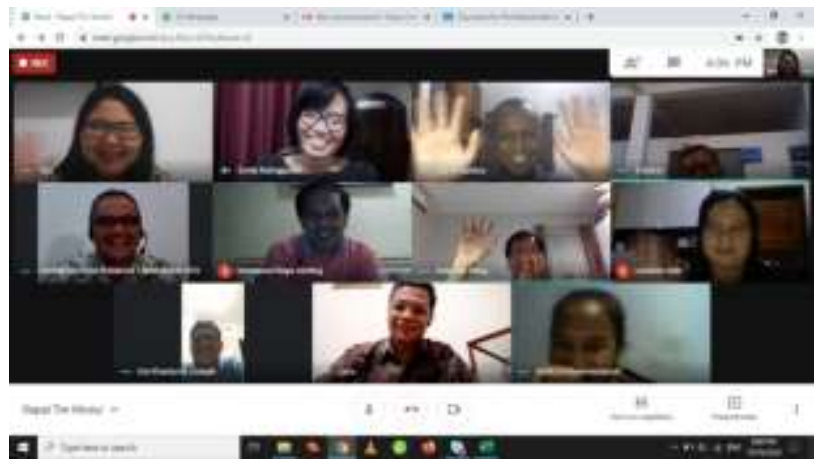

Gambar 3. Dokumentasi FGD 2 (melalui Google Classroom, 11 September 2020)

\section{Strategi Pembiasaan/Integrasi}

Luaran yang ketiga adalah strategi pembiasaan/integrasi yang berhasil dirumuskan peserta dalam FGD 3 yang berlangsung pada 19 Februari 2021. Dengan terumuskannya matriks muatan karakter dan nilai di FGD 2, para peserta dapat melanjutkan tahap persiapan penulisan modul ke FGD 3. Di dalam FGD 3 diharapkan adalah teridentifikasi strategi pembiasaan atau integrasi. Strategi dipahami sebagai pendekatan atau cara yang ditempuh dalam mengimplementasikan pembelajaran karakter dan nilai yang sudah ditentukan agar menjadi pengalaman belajar bagi siswa selama berada di Sekolah Erenos. Strategi pembiasaan/integrasi yang berhasil dirumuskan mencakup hal-hal sebagai berikut.

Pertama, cara yang ditempuh dalam mengimplementasikan pembelajaran karakter dan nilai akan melalui jalur kurikuler, yaitu dengan mengintegrasikan kegiatan-kegiatan yang dirancang ke dalam proses pembelajaran di mata-mata pelajaran. Sekolah Erenos menempatkan pembelajaran tentang karakter dan nilai menjadi bagian dari struktur program, menggunakan alokasi waktu yang telah ditentukan, dan kegiatan dilakukan oleh guru dan peserta didik dalam jamjam pelajaran.

Kedua, pembelajaran jenis karakter dan nilai dalam setiap jenjang akan dilakukan sama, tapi dengan tingkat kedalaman berbeda pada setiap jenjang.

Ketiga, pembelajaran muatan karakter dan nilai akan dilakukan dalam satu tahun pelajaran namun penyajian secara blok mengikuti tiga karakter utama.

Keempat, alokasi waktu yang akan diberikan untuk pembelajaran karakter dan nilai adalah kombinasi sepanjang tahun dan pada waktuwaktu tertentu.

Kelima, pembelajaran akan mencakup semua mata pelajaran.

Keenam, evaluasi keberhasilan pelaksanaan akan dilakukan secara berkala dalam satu tahun pelajaran menggunakan salah satu atau kombinasi instrumen (observasi, kuesioner, dan FGD).

\section{Modul Penyajian}

Luaran keempat dari pendampingan dan 
fasilitasi yang dilakukan adalah rumusan modul penyajian yang didapatkan melalui FGD 4 yang berlangsung pada 7 Mei 2021. Memasuki FGD 4 Sekolah Erenos telah memiliki matriks muatan karakter dan nilai, rencana aktivitas pembiasaan untuk setiap nilai, strategi pembiasaannya. FGD 4 difokuskan untuk merumuskan kesepakatan tentang model penyajian.

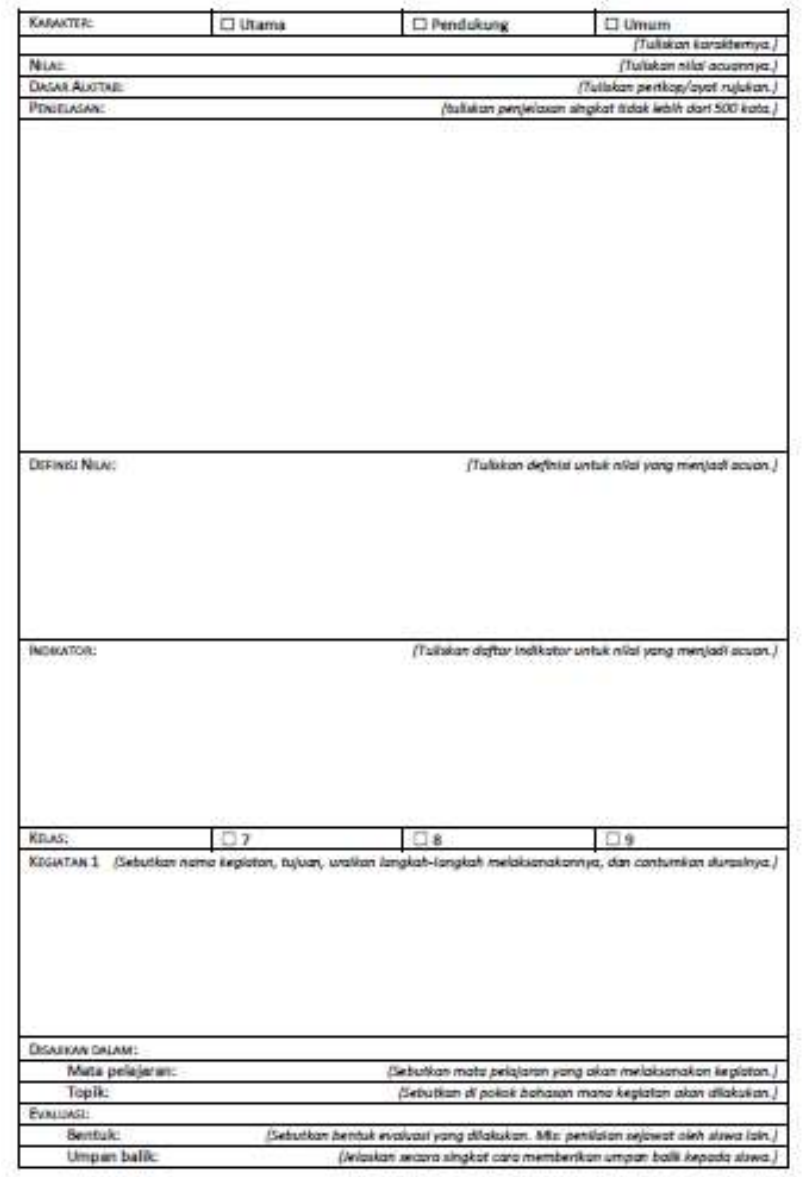

Gambar 4. Model Penyajian

Adapun yang dimaksudkan dengan model penyajian adalah format sebagaimana terlihat dalam Gambar 4 yang akan digunakan untuk mendeskripsikan setiap kegiatan pembiasaan nilai termasuk evaluasi yang akan dilakukan untuk setiap kegiatan. Format ini berisi keterangan tentang: karakter, nilai, dasar Alkitab, penjelasan, definisi nilai, indikator, kelas, rincian kegiatan, mata pelajaran dan topik tempat penyajiannya, serta bentuk evaluasi dan umpan balik kepada siswa.

Di dalam FGD 4 peserta juga menyepakati sejumlah hal yang dijadikan rujukan dalam menulis modul mengikuti model penyajian yang berhasil dirumuskan. Penulisan modul untuk SMP dijadikan sebagai pilot project. Penyajian kegiatan dilakukan per-blok sesuai urutan karakter. Pengisian model dilakukan sebanyak nilai yang akan ditanamkan (35); satu form mewakili satu nilai. Semua kegiatan untuk satu nilai, langsung diuraikan dalam formulir yang sama. Penanaman/pembiasaan nilai dirancang dengan membedakan prosesnya di setiap jenjang kelas (SMP: tiga kelas, tiga proses). Kegiatan boleh sama untuk setiap kelas atau semua jenjang, tetapi dibedakan kedalaman dan luarannya. Penanaman/pembiasaan dilakukan melalui mata pelajaran/topik tertentu. Penanaman/pembiasaan harus terbagi ke semua mata pelajaran dalam setiap jenjang, walaupun akan ada mata pelajaran tertentu yang akan mendapatkan porsi yang besar.

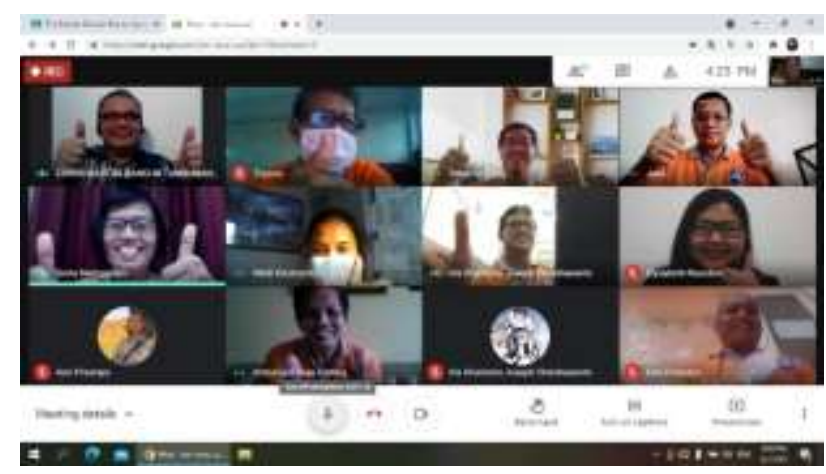

Gambar 5. Dokumentasi FGD 4 (melalui Google Classroom, 7 Mei 2021)

\section{Refleksi}

Pakar transformasi konflik John Paul Lederach menyatakan bahwa pekerjaan membangun perdamaian adalah pekerjaan yang sulit meskipun bukan pekerjaan yang mustahil (Lederach, 2003). Pernyataan Lederach ini mendapatkan pembuktian dalam proses yang dilalui oleh Tim Youth \& Peace Project, Universitas Pelita Harapan bersama dengan 
Sekolah Erenos. Adalah tidak mudah bagi kedua tim untuk tiba pada hasil yang diharapkan, yaitu tersedianya model penyajian kegiatan dalam modul yang dirancang untuk mengembangkan karakter damai melalui pembiasaan nilai-nilai yang dirumuskan berdasarkan visi dan misi sekolah. Upaya yang dilakukan melalui proses panjang dan hasilnya tidak bisa didapatkan dalam waktu singkat. Setelah model penyajian didapatkan, tim penulis dari Sekolah Erenos masih harus melanjutkan pekerjaan di tahap kedua untuk melakukan penulisan sebelum modul tercetak yang bisa diimplementasikan di kelas dapat tersedia.

Transformasi yang dilakukan dalam membangun perdamaian memang memerlukan proses panjang. Layaknya menyusun gambar dalam jigsaw puzzle demikianlah upaya membangun perdamaian. Melalui FGD yang dilakukan, peserta bekerja menyatukan dan merumuskan bagian demi bagian dengan harapan akhirnya tersedia rumusan akhir bagi Sekolah Erenos untuk dapat membiasakan karakter dan nilai-nilai perdamaian merujuk pada visi dan misi yang dimiliki. Bentuk utuh hasil pekerjaan baru mulai terlihat setelah proses panjang menggabungkan potongan-potongan gambar dari FGD yang satu ke FGD berikutnya berhasil dilakukan. Istilah yang sering dipakai untuk menggambarkan proses melelahkan dalam mendorong upaya bina damai seperti yang dilakukan Sekolah Erenos adalah "Peace by Piece."

Pekerjaan bersama yang dilakukan oleh Tim Youth \& Peace Project, Universitas Pelita Harapan dan Sekolah Erenos, juga mewakili hal yang dinyatakan Lederach yaitu membangun perdamaian tidak harus top-down. Mewujudkan perubahan atau transformasi untuk menanamkan karakter dan nilai-nilai perdamaian bisa dimulai dari hal hal sederhana dan kecil. Seperti yang dilakukan oleh Sekolah Erenos, prosesnya berlangsung dari bawah atau dikenal dengan istilah "peacebuilding from below."

(Ramsbotham, Woodhouse \& Miall, 2008, pp. 217221).
Kemauan Sekolah Erenos untuk melakukan bina damai melalui penyusunan modul pembiasaan/integrasi keterampilan perdamaian dan resolusi konflik menegaskan posisi strategis indvidu dalam membantu mewujudkan perdamaian dalam skala lebih luas. Arthur Stein, salah seorang penganjur pendekatan transformatif, mengemukakan peran individu dulu cenderung diabaikan dalam membangun. Dalam pandangan Stein, upaya membangun perdamaian justru harus dimulai dari tingkat akar rumput atau dari individu. Transformasi global akan berlangsung lebih mudah apabila individu memiliki kesadaran bahwa memiliki suasana damai lebih menguntungkan. Kesadaran semacam ini akan memperkuat komitmen individu untuk menjaga perdamaian. Apabila individu, kelompok, dan masyarakat semakin banyak mengambil bagian dalam proses semacam ini, relasi antarbangsa akan mengalami perubahan dan memperkuat upaya bersama dunia mewujudkan perdamaian (Stein, 2004, pp. 565581).

Upaya Sekolah Erenos yang difasilitasi oleh Tim Youth \& Peace Project, Universitas Pelita Harapan adalah contoh baik dalam mengembangkan model pendidikan perdamaian sebagaimana ditawarkan oleh Alev Yemenici. Upaya menanamkan nilai-nilai perdamaian perlu melibatkan tiga kelompok besar sebagai target, yaitu: anak-anak (termasuk Taman Kanak-kanak, Sekolah Dasar, dan Sekolah Menengah Pertama), remaja/dewasa muda (termasuk peserta didik Sekolah Menengah Atas dan mahasiswa), serta kelompok dewasa (orang tua/calon orang tua, pendidik, hingga kaum profesional muda/produktif). Bentuk program yang dilaksanakan tentu berbeda untuk tiap kelompok meski tapi esensi nilai yang disampaikan boleh jadi sama (Yemenici, 2016, pp. 7-9).

Menjadikan SMP sebagai pilot project juga sangat strategis karena salah satu kelompok usia dalam masyarakat yang signifikan populasinya dan kelak menjadi generasi pemimpin adalah kelompok 
remaja. Perhatian kepada remaja perlu diberikan secara serius karena di fase ini terjadi perkembangan psikososial yang dikenal dengan "identitas versus kebingungan." Di kalangan remaja perlu dibangun identitas pribadi sebagai bagian dari masyarakat. Kegagalan membangun hal ini akan menimbulkan kebingungan bagi mereka tentang siapa dan apa yang perlu mereka kerjakan dalam hidupnya (Sandy,2006, pp. 356-358). Diharapkan modul ini kelak menjadi contoh yang dapat diadopsi sekolah-sekolah lain.

FGD dan lokakarya yang dipilih oleh Tim Youth \& Peace Project, Universitas Pelita Harapan sebagai bentuk-bentuk kegiatan untuk memfasilitasi dan mendampingi Sekolah Erenos sangat menentukan keberhasilan mencapai sejumlah luaran yang diperlukan untuk persiapan penulisan modul. Kombinasi FGD dan lokakarya menjadi pilihan karena melalui kegiatan-kegiatan ini peserta leluasa untuk berpartisipasi aktif. Keterlibatan peserta sangat ditekankan dalam proses membangun perdamaian dari bawah (peace from below). Melalui FGD dan lokakarya, peserta dimungkinkan untuk belajar dari pengalaman yang mereka dapatkan. Selain itu, memberi kesempatan luas bagi peserta untuk belajar bekerja sama memecahkan masalah bersama. Rasa kepemilikan (ownership) atas luaran yang dihasilkan juga sangat kuat. (Raider, Coleman \& Gerson, 2006, pp. 695-725; Francis, 2006, pp. 151-163).

\section{Keberlanjutan}

Penulisan modul yang saat ini dilaksanakan oleh Tim Sekolah Erenos mengikuti muatan nilai dan karakter dari visi sekolah, strategi pembiasaan, dan model penyajian yang dihasilkan melalui sejumlah FGD dan lokakarya, membuktikan bahwa pendampingan dan fasilitasi yang dilakukan oleh Tim Youth \& Peace Project memberi dampak kepada target. Selain mengindikasikan dampak dari kegiatan yang dilakukan, penulisan modul pembiasaan juga menunjukkan adanya keberlanjutan dalam dua hal. Pertama, keberlanjutan program Pelatihan Keterampilan Perdamaian dan Resolusi Konflik yang sebelumnya telah dilaksanakan Tim Youth \& Peace Project UPH di Sekolah Erenos. Kedua, keberlanjutan penanaman nilai-nilai dan pengembangan karakter perdamaian dan resolusi konflik oleh sekolah. Melalui pendampingan dan fasilitasi yang dilakukan, sekolah diberdayakan untuk menjamin keberlanjutan program melalui modul pembiasaan yang disusun. Tim Youth \& Peace Project dan Tim Sekolah Erenos akan terus bekerja sama untuk memonitor penerapan modul pembiasaan dan mengembangkannya lebih lanjut sesuai kebutuhan di masa mendatang.

\section{KESIMPULAN}

Fasilitasi dan pendampingan yang dilakukan oleh Tim Youth \& Peace Project, Program Studi Hubungan Internasional, Universitas Pelita Harapan telah berhasil membantu Tim Sekolah Erenos dalam menghasilkan luaran penting yang menjadi fondasi penyusunan modul pembiasan/integrasi keterampailan perdamaian dan resolusi konflik. Melalui FGD dan lokakarya yang diselenggarakan Tim Sekolah Erenos telah berhasil merumuskan muatan nilai dan karakter dari visi sekolah, strategi pembiasaan, dan model penyajian.

Sejumlah luaran yang dicapai telah menjadi rujukan tim dalam menulis modul. Melalui modul yang tersusun dan kemudian diimplementasikan dalam proses pembelajaran, Sekolah Erenos telah berkontribusi dalam melaksanakan bina damai. Dampak dari proses pembiasaan yang dilakukan tentu tidak dapat teramati dalam waktu cepat. Namun, meski penanaman dan pengembangan karakter memerlukan waktu, dalam jangka panjang dampaknya akan terlihat dan terasa.

Tidak dapat dipungkiri, pandemi Covid-19 menjadi tantangan tersendiri dalam proses penyusunan modul dan sebagai sebuah pilot project, keterbatasan sumber daya manusia baik dari tim pelaksana maupun mitra merupakan hambatan yang nyata. Namun, komitmen Tim PkM Youth \& Peace 
Project bersama Sekolah Erenos membuktikan kemajuan signifikan dalam penyusunan modul meskipun ada penundaan yang tidak terhindarkan. Komitmen ini perlu terus dijaga hingga proses penulisan modul selesai dengan terus mengingat kontribusi besar yang akan dihasilkan dari implementasi modul di Sekolah Erenos kelak.

\section{UCAPAN TERIMA KASIH}

Ucapan terima kasih disampaikan kepada Yayasan Sekolah Erenos dan guru-guru yang telah memberikan kontribusi dalam pelaksanaan kegiatan tahap pertama penyusunan modul pembiasaan/integrasi keterampilan perdamaian dan resolusi konflik.

\section{REFERENSI}

Dougherty, K. P. (2007). Habituation and Character Change. Philosophy and Literature, 31(2), 294-310.

Francis, D. (2006). Teori Dasar Transformasi Konflik Sosial. Yogyakarta: Quills.

Kerr, J. (2011). Habituation: A Method for Cultivating Starting Points in the Ethical Life. Journal of Philosophy of Education, 45(4), 643-655.

Lederach, J.P. (2003). The Little Book of Conflict Transformation. Philadelphia: Good Books.

Raider, E., Coleman, S., \& Gerson, J. (2006). Teaching Conflict Resolution Skills in a Workshop. In Deutsch, M., Coleman, P.T., \& Marcus, E. C. (Eds). The Handbook of Conflict Resolution Theory and Practice (pp. 695-725). San Francisco, CA: John Wiley \& Sons, Inc.

Ramsbotham, O., Woodhouse, T., \& Miall, H. (2008). Contemporary Conflict Resolution. Cambridge: Polity Press.

Sandy, S.V. (2006). The Development of Conflict Resolution Skills Preschool to Adulthood. In Deutsch, M., Coleman, P.T., \& Marcus,
E. C. (Eds). The Handbook of Conflict Resolution Theory and Practice (pp. 356388). San Francisco, CA: John Wiley \& Sons, Inc.

Stein, A. (2004). The Individual and Global Peace Building: A Transformational Perspective. In Genest, M.A. (Ed.). Conflict and Cooperation: Evolving Theories of International Relations (pp. 565-581). Belmont, CA: Wadsworth.

Tambunan, E. (2008). Modul Pendidikan Perdamaian untuk Sekolah Menengah Atas (SMA) dan Sekolah Menengah Kejuruan $(S M K)$. Jakarta: Majelis Pendidikan Kristen di Indonesia.

Yemenici, A. (2016). Peace Education: Training for an Evolved Consciousness of NonViolence. All Azimuth: A Journal of Foreign Policy and Peace, 5(1), 5-27. 